Int. J. Dev. Biol. 49: 707-716 (2005)

doi: $10.1387 / \mathrm{ijdb} .051990 \mathrm{ag}$

\title{
Control of reproduction by Polycomb Group complexes in animals and plants
}

\author{
ANNE-ELISABETH GUITTON and FREDERIC BERGER* \\ Chromatin and Reproduction Group, Temasek Lifescience Laboratory, National University of Singapore, Singapore
}

\begin{abstract}
In both mammals and plants, Polycomb Repressive Complexes 2 (PRC2) are conserved and appear to be involved in the transition between vegetative or somatic and reproductive state in plants and mammals. In plants at least three different PRC2 control temporal aspects of development, and mutations in PcG cause heterochronies. Such heterochronic mutations affect the transition to flowering. During gametogenesis the Fertilization-Independent Endosperm-MEDEAPRC2 (FIE-MEA PRC2) complex controls gametogenesis in synergy with a Retinoblastoma-dependent pathway. Several genes of the FIE-MEA pathway are imprinted as shown by their uniparental allele expression in the endosperm, the interface controlling maternal nutrition of the embryo in the seed. Imprinting is also a major feature for genes expressed in the placenta in mammals. Recent data have shown that imprinting in both placenta and endosperm likely share similar mechanisms involving cooperation between the PRC2 complexes and DNA methylation.
\end{abstract}

KEY WORDS: polycomb, endosperm, flowering, reproduction, placenta

Flowering plants and mammals are characterised by full maternal control of their sexual reproduction. Fertilisation occurs inside the maternal reproductive tract and the mother nurtures the embryo through a specialised interface, the placenta in mammals and the endosperm in flowering plants. The placenta develops from a specific mass of cell, the trophoblast, set apart after the first divisions of the embryo. The endosperm is the product of fertilisation of a secondary female gamete, the central cell. The central cell is genetically identical to the egg cell. In most plant species the central cell contains two copies of the maternal genome, leading to triploid endosperm. The fertilised egg cell gives rise to the embryo. As the two male gametes of a given pollen tube originate from a single mitosis, they are genetically identical and their zygotic fusion products are also genetically identical. In spite of their unique genetic identity, the embryo and the specialised maternal interface structure (endosperm or placenta) follow very divergent developmental pathways. Such divergence can only be accounted for by different controls of the genome expression potential. Epigenetic regulation involving changes in DNA methylation and in the histone code are likely mechanisms responsible for large-scale expression changes. Histone 3 modifications are mediated in part by Polycomb Group (PcG) class complexes. In plants, PcG genes have a strong impact on the control of the transition to reproductive phase and in endosperm development. In mammals there has been recent evidence that Polycomb Repressive Complexes 2 (PRC2) class of chromatin remodelling complexes control placenta development. These recent findings will be reviewed and put in perspective with recent advances obtained in plants.

\section{PRC2 type PcG complexes control H3 methylation}

DNA in eukaryotic nuclei is compacted into a structure called chromatin. The basic unit of chromatin is the nucleosome, consisting of 146 base pairs of DNA wrapped 1.8 superhelical turns around an octamer of the core histones $\mathrm{H} 2 \mathrm{~A}, \mathrm{H} 2 \mathrm{~B}, \mathrm{H} 3$ and $\mathrm{H} 4$ (Kornberg, 1974; Kornberg and Thomas, 1974). Chromatin is a highly dynamic polymer and its structure can be constantly modified in response to environmental or developmental signals. Basic histone tails protruding from the histone octamer have been shown to be essential regulators of such dynamics (Luger and Richmond, 1998; Wolffe and Hayes, 1999). Among proteins involved in histone code establishment and interpretation, the Polycomb (PcG) proteins have emerged as major players. Historically, both of these families were discovered in Drosophila (Jürgens, 1985; Lewis, 1978). PcG genes are involved in the maintenance of the segment-specific pattern of Hox genes ex-

Abbreviations used in this paper: EMF, embryonic flower; GTF, general transcription factors; HDAC, histone deactetylase; ICR, imprinting control region; PcG, Polycomb Group; PRC, polycomb repressive complex; SAM, shoot apical meristem; TBP, TATA box binding protein.

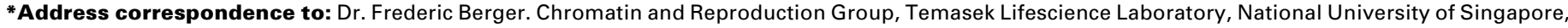
Singapore 117604, Singapore. Fax: +65-6872-7007. e-mail: fred@tll.org.sg
} 
pression initially set up by segmentation genes (Jones and Gelbart, 1990; Simon et al., 1992; Struhl and Akam, 1985). PcG proteins bind hundreds of sites on polytene chromosomes. Thus it has been suggested that they have a global role in gene silencing and that they may also regulate the expression of nonhomeotic genes (DeCamillis et al., 1992; Rastelli etal., 1993; Zink and Paro, 1989).

Two distinct Polycomb Repressive Complexes PRC1 and PRC2 have been purified and characterised in the Drosophila embryo. PRC1 contains the PcG proteins Polycomb (Pc), Polyhomeotic (Ph), Posterior sex combs (Psc) and Sex combs on midleg (Scm) (Shao et al., 1999). The size of PRC1 complex is estimated at 2 MDa (Franke et al., 1992). Two more recent studies have shown that the PRC1 complex contains a number of other factors, including dRING1, a RING finger protein (Saurin et al., 2001) and general transcription factors (GTFs) (Breiling et al., 2001). Furthermore, both these studies have shown that the $\mathrm{PcG}$ proteins $\mathrm{Pc}, \mathrm{Ph}$ and PSC co-immunoprecipitate with the TATA box binding protein (TBP). The finding that general transcription factors are part of the PRC1 complex strongly suggests an interaction between PcG repression and the transcription machinery. Shao et al. (1999) showed that the PRC1 core complex, if preincubated with a nucleosomal array, is able to inhibit chromatin remodelling by a human SWI/SNF ATP-dependent complex. SWI/SNF complexes are able to provoke nucleosome sliding and loosen heterochromatin structure. Altogether, these data support a model in which PcG PRC1 complex protects chromatin structure against remodelling and, in parallel, directly inhibits RNA polymerase II transcription machinery by direct interaction with GTFs and TBP.

A 600kDa PRC2 complex has been purified which is biochemically distinct from the PRC1 complex ( $\mathrm{Ng}$ et al., 2000; Tie et al., 2001). Two PcG proteins, Extra sex combs (ESC) and Enhancer of zeste $E(Z)$ are part of this complex, giving it the name $E S C-E(Z)$ (Fig. 1). Direct interaction between ESC and $E(Z)$ has been demonstrated by independent two-hybrid and co-immunoprecipitation studies (Jones et al., 1998; Tie et al., 1998). Additional studies have identified new subunits of the $\mathrm{ESC}-\mathrm{E}(\mathrm{Z})$ core complex, namely Su(z)12, a PcG zinc-finger protein (Birve et al., 2001; Cao et al., 2002; Muller et al., 2002) and the histone binding protein p55 (Cao et al., 2002; Czermin et al., 2002; Muller et al., 2002, Tie etal., 2001) (Fig. 1). Several studies have shown that the ESC-E(Z) complex has a histone methyltransferase activity, which is necessary for the maintenance of Hox gene repression (Muller et al., 2002). Histone methyltransferase activity is achieved by the $E(Z)$
SET motif and targets H3K27 (tri-methylation) and, to a lesser extent, H3K9 (di-methylation) (Cao et al., 2002; Czermin et al., 2002; Muller etal., 2002). The minimal protein complex required for enzymatic activity consists of E(Z), ESC and p55 (Czermin et al., 2002). Association of the HDAC RPD3 to the ESC-E(Z) complex has also been described (Czermin et al., 2002; Tie et al., 2001) but may be weak (Muller et al., 2002). However, no HDAC activity of the $E S C-E(Z)$ complex has been reported. The identification of $\mathrm{ESC}-\mathrm{E}(Z)$ complex and characterisation of its enzymatic activities highlight the intimate link between PcG proteins and establishment of the histone code.

\section{PRC2 PcG genes and complexes are conserved in mammals and in plants}

Homologues of all major Drosophila PcG genes have been cloned in mammals. A distinct ESC-E(Z)-like complex is composed of EZH2, EED, p55 homologs RbAp46 and RbAp48 and SU(Z)12 (Cao et al., 2002; Kuzmichev et al., 2002). As in Drosophila, there is some evidence that Eed/EED can directly interact with Enx2/ EZH1 and Enx1/EZH2 (Jones etal., 1998; Sewalt et al., 1998; vanLohuizen et al., 1998) but not with PRC1 members HPC2 or BMI1 (Sewalt et al., 1998) and that Eed and Enx proteins are found in a complex distinct from the PRC1 complex that contains Mph1 (van-Lohuizen et al., 1998) (Fig. 1). Recently, interaction between $\mathrm{SU}(\mathrm{Z}) 12$ and EZH2 has been shown (Yamamoto et al., 2004). Whether it is the case in Drosophila is not known but $\mathrm{Su}(\mathrm{z}) 12$ is detected in the $600 \mathrm{kDa}$ ESC-E(Z) complex (Ng et al., 2000, Tie et al., 2001). An association of EED with HDAC1 and HDAC2 has been reported (van-der-Vlag and Otte, 1999) but, as is the case in fly, may be weak or transient (Kuzmichev et al., 2002). The homolog of Pho, Yin Yang 1 (YY1) is part of EED-EZH complexes in both mouse and human (Satijn et al., 2001) and directly interacts with EED. This striking conservation of protein interactions and complex formation is reinforced by the finding that EED-EZH complex has also a H3K27-specific Histone Methyltransferase activity on H3-Lys27 (Cao et al., 2002; Kuzmichev et al., 2002).

Thus, PcG complexes are very well conserved in terms of composition and molecular function between Drosophila and mammals. However, the duplication of almost all PcG genes in mammals allows variations in complex composition, depending on cell or tissue type (Lessard and Sauvageau, 2003b). For example, $\mathrm{HPH} 2$ is expressed in all tissues tested, whereas HPH1 is expressed only in testis, ovary and thymus (Gunster et al., 1997)

\section{Drosophila}

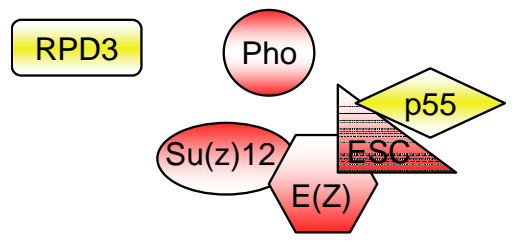

Arabidopsis

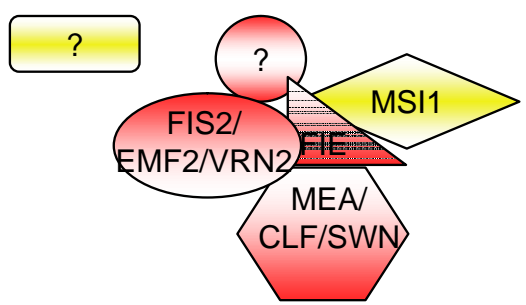

Human

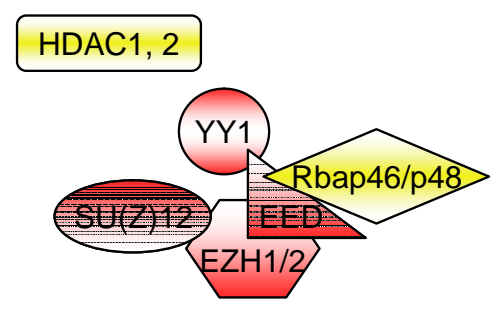

Fig. 1. Polycomb repressive complex 2 (RC2) PcG complexe homologues. Several homologues of PcG genes exist in Drosophila, mammals and Arabidopsis. They are all associated in stereotypical complexes. The homologues are indicated in the same box. Mammalian and Arabidopsis complexes do not necessarily contain all the homologues that are represented in the same box. 
where it could participate to a new complex for new functions.

In addition to fly and mammals, conservation of PcG genes and the PRC2 complex, is also obvious in plants. Several PcG genes have been cloned in Arabidopsis thaliana. In Arabidopsis, the first PcG gene identified was CURL YLEAF (CLF), homologous to $\mathrm{E}(\mathrm{Z})$ (Goodrich et al., 1997). E(Z) homologues in Arabidopsis constitute a family of three genes, CLF, its closest relative SWINGER (SWN ) (Chanvivattana et al., 2004) and MEDEA (MEA) (Grossniklaus et al., 1998); (Luo etal., 1999). Arabidopsis genome contains a single homologue of ESC, FERTILISATION INDEPENDENT ENDOSPERM (FIE) (Ohad etal., 1999; Luo etal., 1999). As ESC and $\mathrm{E}(\mathrm{Z})$ proteins interact in Drosophila, direct interaction between FIE and MEA has been tested. Two-hybrid studies, confirmed by GST pull-down assays, showed that FIE and MEA are indeed able to directly bind each other in vitro (Luo et al., 2000; Spillane et al., 2000; Yadegari et al., 2000). In vivo interaction was recently demonstrated (Bracha-Drori et al., 2004). The FIE-MEA complex has been isolated and also shown to contain MSI1 (Kohler et al., 2003a), homologous to the Drosophila histone binding protein p55 (Hennig et al., 2003). Homologues of Su(z)12, the fourth conserved member of PRC2 complexes are encoded by a family of three genes, FERTILISATION INDEPENDENT SEED 2 (FIS2) (Luo et al., 1999), EMBRYONIC FLOWER 2 (EMF2) (Yoshida et al., 2001) and VERNALISATION2 (VRN2) (Gendall et al., 2001). It was shown recently that each of the Arabidopsis Su(z)12 protein are able to interact through the conserved VEFS domain with the conserved cysteine rich $C 5$ domain in each member of the $E(Z)$ family (Chanvivattana et al., 2004). Although only the FIE-MEA complex has been biochemically isolated and is present in the female gametes and in developing endosperm in the seed, distinct PRC2 complexes can be envisaged as some members have nonoverlapping patterns of expression. Functional analysis of CLF and SWN shows a large degree of redundancy whereas distinct functions have been ascribed to EMF2 and VRN2 during vegetative life. Hence it can be proposed that the Su(z)12 members are essential for the specific association of PRC2 with a selected set of target genes (Chanvivattana et al., 2004). It is thus possible to conclude to a strong conservation of PRC2 complexes core members ESC, E(Z), Su(z)12 and p55. In some organisms as the nematode $\mathrm{C}$. elegans, $\mathrm{Su}(\mathrm{z}) 12$ has been lost during evolution and strikingly the $C 5$ domain of the $E(Z)$ homologue MES2 has not been conserved (Holdeman et al., 1998); (Chanvivattana et al., 2004). The molecular mass of the FIE-MEA complex is still higher than can be accounted for by the four conserved core members of PRC2 complexes (Kohler etal., 2003a). A large family of HDAC is present in Arabidopsis, yet no member has been identified in the FIE-MEA complex. Also, there is no obvious homologue of Pho and Yin Yang 1 (YY1).

\section{PRC2 complexes control the transition through devel- opmental phases in plants}

Flowering plant life cycle is characterised by alternation of several phases corresponding to a series of transition towards reproduction. After seed germination, the seedling emerges and develops into a rosette. Rosette development is the result of leaf formation, without elongation of shoot internodes. The stem cells forming the shoot apical meristem (SAM) are responsible for leaf initiation, whereas the opposite root apical meristem is at the origin of root growth. Vegetative development ends as a result of integration of endogenous and environmental signals. This corresponds to floral transition of the vegetative SAM to an inflorescence SAM identity. A second major transition is the conversion of the inflorescence SAM into a specialised flower meristem. A third major transition takes place within the sexual organs of flowers, when meiosis is initiated leading to the haploid gametophytic phase. Gametes are produced by specialised haploid structures, the gametophytes. Gametophyte development is arrested at gamete maturation and the double fertilisation process initiates the subsequent sporophytic phase, namely seed development, requiring coordinated development of the embryo and the endosperm. All of these developmental phase transitions have to be tightly regulated in order to ensure the integrated development of the plant. We will present how PcG proteins are essential in such processes.

\section{Control of flowering time by vernalisation requires a PcG protein and involves histone modifications}

In winter annual plants, an essential pathway controls flowering time: vernalisation. Vernalisation is described as 'the acquisition or acceleration of the ability to flower by a chilling treatment' (Chouard, 1960). This process allows flowering only when the cold season has passed. Vernalisation requires cellular memory processes, as plants often flower weeks after they have been exposed to cold. The meristem is the centre of cold memory (Metzger, 1988; Schwabe, 1954). A central gene in the integration of vernalisation signal is the MADS box gene FLOWERING $\angle O C U S C$ (FLC). High level of $F L C$ expression represses flowering. $F L C$ expression is promoted by the protein $F R / G I D A$ (Johanson et al., 2000; Michaels and Amasino, 1999; Sheldon et al., 1999). In contrast, cold treatment induces a downregulation of FLC expression, which is maintained after transfer to normal temperature and accelerates flowering (Michaels and Amasino, 1999; Sheldon et al., 1999). Screens for mutants affected in the response to vernalisation have isolated some key factors involved in the long-term repression of $F L C$ after cold exposure. Mutations in VERNALIZATION 1 (VRN1) (Levy et al., 2002) or VRN2 (Gendall et al., 2001) prevent vernalisation-induced flowering. VRN1 is a DNA-binding protein and VRN2 is a PcG protein, homologue of $\mathrm{Su}(\mathrm{z}) 12$. VRN1 and VRN2 expression is detected in all tissues, at all developmental stages and is not induced by cold exposure. In vrn mutants, FLC down regulation is induced during cold treatment, but $F L C$ expression is recovered when plants are transferred to normal growth temperature. These results suggest that $V R N 1$ and $V R N 2$ genes are involved in maintenance, but not the establishment, of FLC MADS box gene repression after cold exposure. VRN1 and VRN2 present fundamental characteristics of PcG proteins: they are ubiquitously expressed, are involved in the maintenance of gene repression and are regulators of development.

Recent work has partially elucidated the mechanism by which PcG mediated repression is established and maintained at the FLC locus (Sung and Amasino, 2004). In the vernalization insensitive 3 (vin3) mutation, the response to vernalisation is abolished. VIN3 protein contains a Plant Homeodomain (PHD) motif, which is characteristic of chromatin remodelling factors (Aasland et al., 1995). VIN3 is specifically and transiently ex- 
pressed in shoot and root apical meristems during cold exposure, i.e. in cells where FLC expression must be repressed. Furthermore, $F L C$ expression is never repressed in vin3 mutants, even after long exposure to cold temperature. These data provide evidence that VIN3 is responsible for the establishment of FLC repression. As VIN3 is only transiently expressed, it is reasonable to hypothesize that VRN1 and VRN2 maintain the repression initiated by VIN3. There is also evidence that an epigenetic control of $F L C$ expression is mediated by histone modification (Bastow et al., 2004; Sung and Amasino, 2004). In the absence of vernalisation, the $F L C$ promoter and first intron, both of which are necessary for vernalisation response (Sheldon et al., 2002), are acetylated on histones consistent with active expression. Vernalisation induces a deacetylation of histones on these regulatory regions. Histone deacetylation establishment is dependent on VIN3 protein, whereas VRN1 and VRN2 are necessary for its maintenance. Vernalisation treatment also induces methylation of lysines 9 and 27 on histone H3 (H3K9/H3K27) and this methylation is VRN2-dependent. By homology with animals, one can speculate that VRN2 is part of a PcG complex, containing FIE, MSI1 and CLF or SWN (Fig. 2).

\section{Control of flowering time requires also the EMF2 PRC2}

$C L F$ controls flowering time as loss-of-function clf alleles show precocious flowering (Fig. 2). Reduction of flowering time is increased when weak clf alleles are combined with the weak alleles of emf2 (Chanvivattana et al., 2004). Similarly precocious flowering is observed in plant with reduced amounts of FIE transcripts (Katz et al., 2004b) or of MS/1 transcripts (Hennig et al., 2003). Hence, the EMF2 PcG complex also controls floral transition. The fact that strong alleles of emf2 (Yang et al., 1995; Yoshida et al., 2001) and strong suppression of FIE (Kinoshita et al., 2001) cause seedlings to flower indicate that the EMF2 complex maintains the vegetative phase from late embryogenesis onwards.

\section{Floral transition and flower development are closely related in Arabidopsis and controlled by the EMF2 PcG complex}

$\angle E A F Y$ (LFY) and APETALA1 (AP1) genes are essential transcription factors for flower initiation (Mandel et al., 1992; Weigel et al., 1992). When developmental and environmental conditions are favourable, $\angle F Y$ expression is induced. Activation of $A P 1$ expression by $\angle F Y$ provokes SAM transition from a vegetative to a reproductive state, producing inflorescences (Fig. 2). Constitutive expression of $\angle F Y$ (Weigel and Nilsson, 1995) or AP1 (Mandel and Yanofsky, 1995) accelerates floral transition, showing that their expression must be repressed as long as a flowering decision has not been made. $\angle F Y$ is necessary later for activation of floral organ identity gene expression. Loss-of-function in EMF2 leads to early activation of LFY and precocious transition from a vegetative to an inflorescence meristem. Furthermore, emf2 mutations lead to derepression of homeotic genes that control flower development (Moon et al., 2003), leading to abnormal flower development. A similar deregulation of floral homeotic genes patterns with corresponding flower abnormalities is observed in c/f and c/f swn double mutants
(Chanvivattana et al., 2004) and in plants with reduced levels of FIE or MS/1 transcripts (Katz et al., 2004; Hennig et al., 2003; Kinoshita et al., 2001). These data indicate that the EMF2 complex regulates both floral transition and flower development (Fig. 2). However the PcG complex has not been formally isolated. Another question remains as to how repression is broken when flowering time arises? Expression data of PcG genes show that the process is not transcriptionally regulated, but no alternative model has been proposed.

The control of floral transition is an example in which a parallel between Arabidopsis and animals PcG proteins can be drawn. Inflorescence meristems in Arabidopsis produce flower buds as long as the plant is alive. Interestingly, when MS/1 or FIE are silenced a terminal flower is produced after the production of only a few flowers and a similar phenotype is observed in emf2 (Chen et al., 1997; Hennig et al., 2003; Katz et al., 2004a; Yang et al., 1995). Such an early termination of flower production by the inflorescence meristem can be interpreted as a loss of maintenance of stem cell identity. This phenotype shows that the EMF2 complex is required for the maintenance of stem cells identity, preventing their differentiation. A similar link between PcG function and stem cell identity has been demonstrated in humans (Lessard and Sauvageau, 2003a; Ohta et al., 2002). Also target genes of PcG proteins are also well conserved, as main targets of PcG proteins in plants are homeotic genes as is the case in Drosophila and mammals. Histone H3 lysine 27 methylation involvement in $F L C$ regulation further supports the evolutionary conservation of PCG pathways between plants and animals.

\section{The FIE-MEA complex controls double fertilisation and seed development}

After meiosis development of the female gametophyte involves three successive mitoses. After cellularisation of the syncytial gametophyte containing eight nuclei, seven cells form the embryo sac (Fig. 3). The central cell inherits two nuclei and is therefore homodiploid. Once the embryo sac is differentiated, cell division arrests. Double fertilisation is the signal by which development will be re-initiated leading to endosperm and embryo development.

fertilization independent seed (fis) mutants are characterised by autonomous seed formation in absence of fertilisation (Chaudhury et al., 1997, Ohad et al., 1996, Peacock et al., 1995; Kohler et al., 2003a; Guitton et al.,2004). The fis mutants comprise mea, fis2, fie, msi1 and borgia. To the exception of the unidentified BORGIA gene, all fis mutants participate in the genetic pathway controlled by the FIE-MEA complex (Grossniklaus et al., 1998; Luo et al., 1999; Ohad et al., 1999; Guitton et al.,2004). Autonomous seeds in mea, fis2, fie contain only endosperm, resulting from central cell division and no embryo development was reported (Chaudhury et al., 1997; Kiyosue et al., 1999; Ohad et al., 1996). These data confer to the F/S class PcG proteins an essential role in repressing central cell development in the absence of fertilisation. Autonomous seeds produced in msi1 mutant alleles also contain an embryo-like structure, which expresses early embryo markers and acquire an apicalbasal polarity typical of early embryogenesis in higher plants (Guitton and Berger, 2005). Parthenogenetic development of msi1 haploid embryos, arrests after a few cell divisions. This 
arrest probably results from the absence of msit function, shown to be necessary for division in diploid embryos homozygous for msi1 produced by fertilisation in msi1/+ plants (Guitton et al., 2004). This role of plant PcG proteins in controlling cell cycle progression may be mediated via MSI1, which also likely binds the Retinoblastoma homologue RBR1 in Arabidopsis (Ach et al., 1997). Mutants for $R B R 1$ show limited autonomous seed development and abnormal proliferation of the female gametophyte (Ebel etal., 2004). Such a phenotype has also been observed with a low penetrance in msi1 female gametophytes. (Berger, personal communication). Two main scenarios can be envisaged to account for autonomous seed development in fis mutants (Fig. 3). Autonomous seed development results from the absence of cell cycle arrest of the female gametes, which could be mediated directly by loss of MSI1-RBR1 regulation of the transition from G1 to $S$ phase. This control would be modulated by the FIE-MEA complex, notably through direct interaction between MSI1, RBR1 (Mosquna et al., 2004) and FIE (Kohler et al., 2003a). According to an alternative hypothesis, the developmental program of female gametophyte is perturbed earlier by abnormal function of the PcG complex or by another MSI1 containing complex and never achieves proper maturation. Hence the signals required for cell cycle arrest are not executed and the central cell keeps dividing into an endosperm-like structure. Similarly the egg cell, in the case of the most penetrant mutations in msi1, also keeps dividing and initiates limited parthenogenetic development.

When fis ovules are fertilised a maternal effect leads to abnormal seed development. Endosperm development is deeply affected (Kiyosue et al., 1999; Sorensen et al., 2001; Guitton et al., 2004; Ingouff et al., 2005a). Wild type endosperm development undergoes a series of four major developmental phases timed by successive synchronous nuclei divisions (Boisnard-Lorig et al., 2001). The first three phases describe endosperm syncytial development (Fig. 3). After phase 1 consisting of three synchronous nuclei divisions, mitotic domains are defined in phase 2 (relative to stage V). Phase 3 starts with the onset of nuclei migration towards the posterior pole at stage VIII (Guitton et al., 2004). At stage IX cellularisation marks the end of the syncytial phase (phase 4) (Sorensen et al., 2002). In fis endosperm the transition from phase 1 to phase 2 is absent and mitotic domains are either not present of ill-defined (Ingouff et al., 2005a). Accordingly, the expression of seven markers of phase 1 and phase 2 is temporally extended to a later phase of development when endosperm acquires a cellular state in the wild type. In fis seeds, endosperm does not cellularise (Grossniklaus et al., 1998; Kiyosue et al., 1999). Continuance of the initial syncytial state leads to overproliferation after stage IX.
In spite of such changes, specific sequences of developmental events still take place as in the wild type. The pace of cell division is not altered during the early syncytial phase and some anteroposterior pattern elements are normally expressed (Kiyosue et al., 1999; Ingouff et al., 2005a). Overall, fis mutations cause a temporal deregulation in ontogenic sequence of endosperm development and can be defined as heterochronic, leading to a complex pleiotropic phenotype (Ingouff et al., 2005a). The molecular origin of the various aspects of the fis phenotype is not understood. Köhler et al. identified PHERES1 (PHE1) as a direct target of MEA-FIE complex by using microarray analysis (Kohler et al., 2003b). PHE1 belongs to the type I-MADS box transcription factor family and is expressed during early endosperm development but its role is not understood. Another recently identified potential target of the FIE-MEA PcG complex is the actin nucleator FORMIN HOMOLOGY PROTEIN 5 (AtFH5) (Ingouff et al., 2005b). The gene AtFH5 was identified in the enhancer trap line KS117 with an endosperm-specific expression. The GFP marker associated to KS117 is overexpressed in fis mutants. As AtFH5 loss-of-function impairs cellularisation and the development of the posterior pole, both parts of the fis phenotype, it is possible

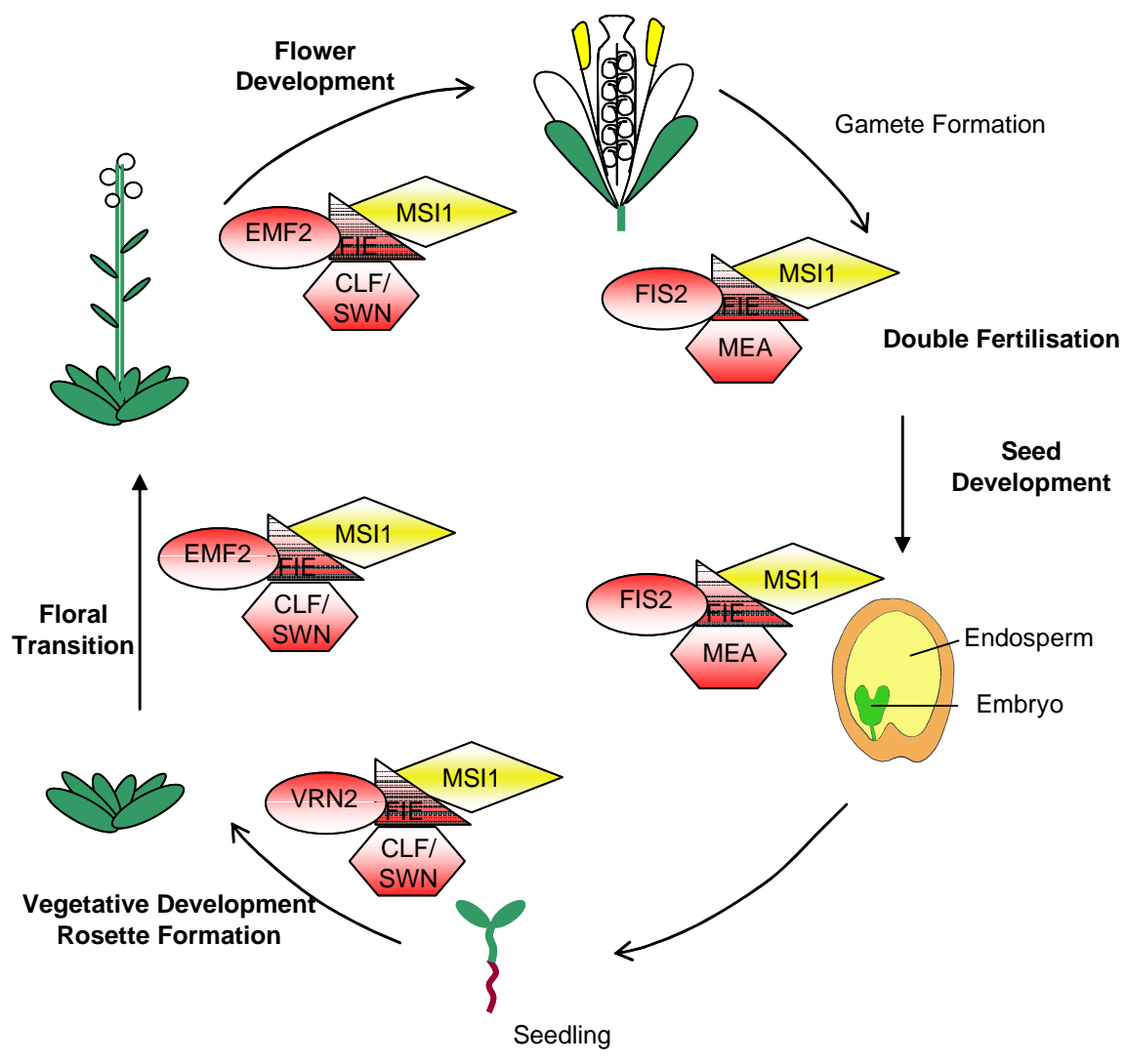

Fig. 2. Control of the Arabidopsis life cycle by PRC2 complexes. Upon germination, the two embryonic cotyledons and primary root emerge. Further development leads to rosette formation and floral transition initiates the inflorescence. The hermaphrodite flower is composed of four whorls: from the outside to the inside, green sepals, white petals, male organs anthers and female organ pistil, which contains ovules. Meiosis takes place in ovules and in developping pollen in anthers and forms the female and the male gametes respectively. Double fertilisation leads to formation of two organisms: the embryo and the surrounding endosperm. Embryo germinates and is at the origin of the next generation. At least three types of PRC2 complexes control several transition from the vegetative to the reproductive phase of Arabidopsis development. 
that AtFH5 mediates some action of the FIE-MEA complex, which could directly control its expression.

\section{Endosperm and placenta development are regulated by imprinting, which involves PRC2 genes}

Promoter fusion, in situ hybridisations and RT-PCR analyses showed that MEA, FIS2 and FIE genes are expressed in the embryo sac, mainly in the central cell and in the endosperm after fertilisation (Grossniklaus et al., 1998; Kinoshita et al., 1999, Kiyosue et al., 1999; Luo et al., 2000; Ohad et al., 1999; Spillane etal., 2000; Vielle-Calzada etal., 1999; Yadegari etal., 2000). FIE is also expressed in the embryo (Luo et al., 2000; Spillane et al., 2000; Yadegari et al., 2000) and some studies report MEA expression in the embryo (Kinoshita et al., 1999; Vielle-Calzada et al., 1999). Whereas FIS2 and MEA seem to be specific for reproductive development, $F / E$ has a wide pattern of expression including sporophytic expression in cauline leaves, stem and roots (Luo et al., 2000; Ohad etal., 1999). Expression of some F/S genes shows a remarkable property as during syncytial endosperm development only the maternal allele is expressed (Berger, 2004). The paternal allele remains silenced. Parental allele dependent gene expression is defined as imprinting. In Arabidopsis parental imprinting has been directly demonstrated only for MEDEA (Kinoshita et al., 1999), for the endosperm specific gene FWA (Kinoshita et al., 2004) and recently for PHERES (Kohler et al., 2005). As expression reporters for FIE and FIS2 show paternal silencing (Yadegari et al., 2000; Luo et al., 2000), it is assumed that corresponding genes are imprinted and only maternally expressed. PHERES is only paternally expressed (Fig. 3). Imprinting of MEA and of FWA involves the maintenance methyltransferase MET1 and the DNA glycosylase DEMETER (Xiao et al., 2003; Kinoshita et al., 2004). MET1 methylates cytosine residues present in $\mathrm{CpG}$ clusters in the
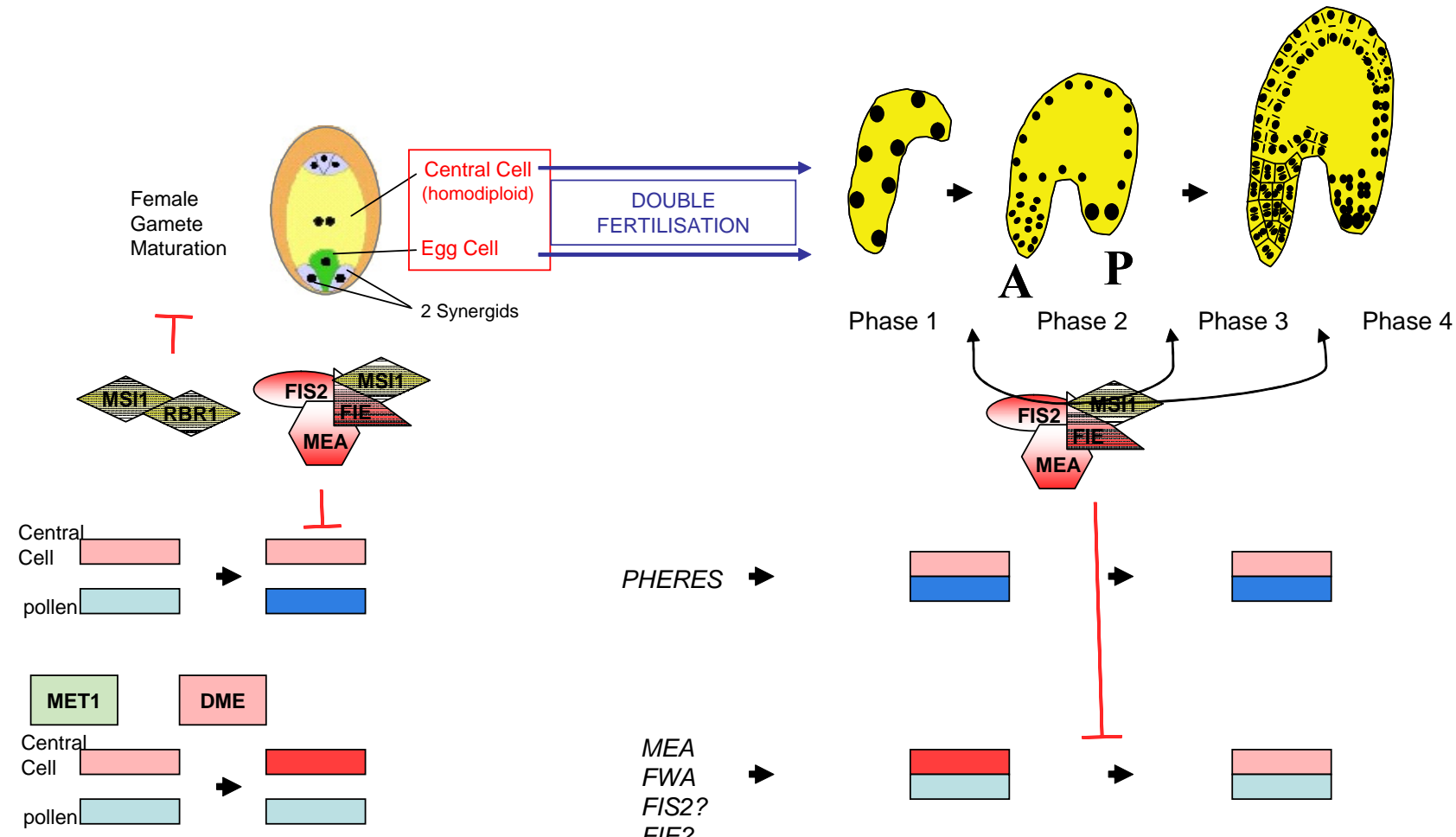

Fig. 3. Control of female gametogenesis and endosperm development by the FIE-MEA complex. Proliferation during female gametogenesis is controlled by the MSI1-RBR1 pathway. Together with the FIE-MEA complex, MSI1 and RBR1 may also control female gametophyte sexual maturation marked by cell cycle arrest in the central cell and in the egg cell. Double fertilisation of the egg cell and the central cell give rise to the embryo and the endosperm respectively. Endosperm developmental phases are delimited by a series of cellular events: the transition from a synchronous mode of syncytial division (Phase 1) to partition of the syncytium in three mitotic domains (Phase 2), the onset of nuclei migration to the posterior pole (P) (Phase 3) located opposite to the anterior pole where the embryo develops (not shown), cellularisation leading to Phase 4 when cellular endosperm differentiate different cell types. The FIE-MEA complex is a positive regulator of the transtition between the different phases. At the molecular level, the FIE-MEA complex regulates the expression of several imprinted genes including genes encoding members of the complex (MEA and most likely FIS2 and FIE). This regulation takes place at two levels. The FIE-MEA complex may act during central cell maturation and maintains the silenced state of PHERES, whereas PHERES expression in initiated during pollen development. Hence after fertilisation, PHERES is imprinted with only expression of the paternal copy. The FIE-MEA complex may further maintain silencing of PHERES maternal allele during endosperm development. MEA and FWA represent another class of imprinted genes with silencing of the paternal allele. Both parental copies are silenced during vegetative development by maintenance of DNA methylation by the methyltransferase MET1. Activation of the maternal allele takes place during central cell maturation through the action of the DNA glycosylase activity of DME. During endosperm development, the expression of imprinted genes becomes repressed after Phase 3 under the action of the FIE-MEA complex. 
promoter and the coding sequence of imprinted genes and participate in maintenance of the silenced state of these genes through the vegetative life cycle. Only in endosperm development, is the promoter of FWA demethylated and the gene become expressed. Demethylation affects only the maternal copy and likely results from the action of DEMETER during female gametogenesis (Fig. 3). DEMETER is expressed specifically in the central cell and is presumed to cause single stranded DNA cuts after cytosin residues, which once repaired with non methylated cytosine residues, would lead to demethylation of the DNA (Choi et al., 2002). Such a mechanism remains to be demonstrated for FIS2 and FIE. In the case of PHERES, maintenance of repression of the maternal allele during endosperm development is at least under the control of FIE-MEA activity (Kohler et al., 2005).

Implication of both DNA maintenance methyltransferases and of PRC2 complexes have been demonstrated in imprinting in mammals. In mammals, where imprinting was originally described, at least eighty genes are affected by this mechanism (Delaval and Feil, 2004). Several imprinted genes are particularly important for placental development (Reik et al., 2003). Most imprinted genes are located in clusters around imprinting control regions (ICR) enriched in CpG islands and subjected to methylation (Reik and Walter, 2001). In contrast to plants, in which imprints are acquired by demethylation, mammalian imprint are mostly acquired by differential methylation of the maternal copy in the egg or of the paternal copy during spermatogenesis (Berger, 2004; Delaval and Feil, 2004; Reik and Walter, 2001). This involves a specific de novo DNA methyltransferase Dnmt3a (Hata et al., 2002; Kaneda et al., 2004; Okano et al., 1999; Okano and Li, 2002; Suetake et al., 2004). The imprint is later maintained in somatic cells as in plants by the methyltransferase Dnmt1. As was recently shown in plants, DNA methylation is not the only mechanism at the origins of imprints in mammals (Umlauf et al., 2004); (Lewis et al., 2004). Several genes at the Kcnq1 and at the lgf2r domains show imprinting in the placenta, which does not depend on DNA methylation. It has been shown recently that imprinting status of the parental allele is linked directly to differential methylation of $\mathrm{H} 3$ with trimethylation at H3-Lys27 and dimethylation at H3-Lys9. Chromatin Immunopurification has shown that Ezh2 and Eed associate with the paternally silenced allele of several imprinted genes in the placenta (Umlauf et al., 2004). It is yet not clear how the PRC2 is differentially recruited to the paternal allele during early embryogenesis, not how the imprinted status is conserved only in the placenta. In mice with loss-of-function of Eed paternal silencing is partially relieved only in some genes of the Kcnq1 domain, indicating that other mechanisms redundant with histone methylation might be involved (Mager et al., 2003). The parallel between imprinting in Arabidopsis endosperm and in mammalian placenta is striking by the conservation of molecular mechanisms involved. Imprinting of MEA involving DME and MET1 activity may also be associated with the function of the FIE-MEA itself as MEA is largely overexpressed in a fie background (Ingouff et al., 2005a), though it is not yet clear whether the change in expression affects only one of the parental alleles.

Imprinting has evolved independently in mammals and in flowering plants and has targeted specifically the interface controlling maternal nutritive supply of the embryo. In both groups, this interface shares identical genetic material with the embryo, yet follows a completely divergent developmental program. It can be hypothesised that chromatin remodelling mechanisms are primarily crucial to keep the embryo lineage apart from the gametophytic lineage in plants and from the placenta lineage in mammals. Imprinting might have secondarily used such chromatin remodelling mechanisms as a result of differential selective evolutive pressure on the parents. In both mammals and plants, imbalance between the maternal and paternal genome dosage causes similar effects (Scott et al., 1998; Barton et al., 1985; Barton et al., 1984; Surani et al., 1984). An increase in paternal dosage leads to increase in placental or endosperm growth, whereas increase in maternal dosage has the opposite effect. Potential effector genes of the parental genome imbalance dosage are not known in plants. The HAIKU class genes controls endosperm growth in Arabidopsis but their molecular nature remains to be identified (Garcia et al., 2005; Garcia et al., 2003). Imprinted $F / S$ genes do not have a direct role in the control of endosperm growth or proliferation (Kiyosue etal., 1999; Ingouff et al., 2005a). Overproliferation observed in fis mutant endosperm occurs only late during development as the likely consequence of preservation of the syncytial state rather than as a direct effect of the mutation. Only MSI1 directly controls endosperm growth and proliferation during the syncytial phase but its imprinted status is not known (Guitton et al., 2004). In mammals, placental growth and proliferation are controlled by the Insulin growth receptor-like 2 factor (Ong et al., 2000), but the role of most genes imprinted in the placenta remains unknown. Besides identification of the cellular and molecular pathways involved in the function of imprinted genes in placenta and in endosperm development, several question remains to be solved. Is the FIE-MEA complex involved in the regulation of paternally imprinted FIS genes? Is imprinting in plants confined to endosperm development? Are other PRC2 active during the vegetative development involved in maintenance of silencing of the endosperm imprinted genes? Are PRC2 genes imprinted in mammals? How are the imprints propagated in endosperm and in the placenta where rapid division take place? To which extent imprinting is linked with parental differentiation or to the stable and drastic isolation of lineages with different fates amongst which are gametes?

\section{Acknowledgments \\ We thank Jonathan Fitzgerald for critical reading of the drafts. A.G. was funded by the French ministry of research.}

\section{References}

AASLAND, R., GIBSON, T.J. and STEWART, A.F. (1995). The phd finger: Implications for chromatin-mediated transcriptional regulation. Trends Biochem. Sci. 20: $56-9$.

ACH, R.A., TARANTO, P. and GRUISSEM, W. (1997). A conserved family of wd40 proteins binds to the retinoblastoma protein in both plants and animals. Plant Cell 9: 1595-606.

BARTON, S.C., ADAMS, C.A., NORRIS, M.L. and SURANI, M.A. (1985). Development of gynogenetic and parthenogenetic inner cell mass and trophectoderm tissues in reconstituted blastocysts in the mouse. Journal of Embryol Exp. Morphol. 90: 267-85.

BARTON, S.C., SURANI, M.A. and NORRIS, M.L. (1984). Role of paternal and maternal genomes in mouse development. Nature 311: 374-6.

BASTOW, R., MYLNE, J.S., LISTER, C., LIPPMAN, Z., MARTIENSSEN, R.A. and DEAN, C. (2004). Vernalization requires epigenetic silencing of flc by histone 
methylation. Nature 427: 164-7.

BERGER, F. (2004). Plant sciences. Imprinting - a green variation. Science 303: 483-5.

BIRVE, A., SENGUPTA, A.K., BEUCHLE, D., LARSSON, J., KENNISON, J.A., RASMUSON-LESTANDER, A. and MULLER, J. (2001). Su(z)12, a novel Drosophila polycomb group gene that is conserved in vertebrates and plants. Development 128: 3371-9.

BOISNARD-LORIG, C., COLON-CARMONA, A., BAUCH, M., HODGE, S., DOERNER, P., BANCHAREL, E., DUMAS, C., HASELOFF, J. and BERGER F. (2001). Dynamic analyses of the expression of the histone::Yfp fusion protein in arabidopsis show that syncytial endosperm is divided in mitotic domains. Plant Cell 13: 495-509.

BRACHA-DRORI, K., SHICHRUR, K., KATZ, A., OLIVA, M., ANGELOVICI, R., YALOVSKY, S. and OHAD, N. (2004). Detection of protein-protein interactions in plants using bimolecular fluorescence complementation. Plant J 40: 419-27.

BREILING, A., TURNER, B.M., BIANCHI, M.E. and ORLANDO, V. (2001). General transcription factors bind promoters repressed by polycomb group proteins. Nature 412: 651-5.

CAO, R., WANG, L., WANG, H., XIA, L., ERDJUMENT-BROMAGE, H., TEMPST, P., JONES, R.S. and ZHANG, Y. (2002). Role of histone h3 lysine 27 methylation in polycomb-group silencing. Science 298: 1039-43.

CHANVIVATTANA, Y., BISHOPP, A., SCHUBERT, D., STOCK, C., MOON, Y.H., SUNG, Z.R. and GOODRICH, J. (2004). Interaction of polycomb-group proteins controlling flowering in arabidopsis. Development 131: 5263-76.

CHAUDHURY, A.M., MING, L., MILLER, C., CRAIG, S., DENNIS, E.S. and PEACOCK, W.J. (1997). Fertilization-independent seed development in arabidopsis thaliana. Proc. Natl. Acad. Sci. USA 94: 4223-4228.

CHEN, L., CHENG, J.C., CASTLE, L. and SUNG, Z.R. (1997). Emf genes regulate arabidopsis inflorescence development. Plant Cell 9: 2011-24.

CHOI, Y., GEHRING, M., JOHNSON, L., HANNON, M., HARADA, J.J., GOLDBERG, R.B., JACOBSEN, S.E. and FISCHER, R.L. (2002). Demeter, a DNA glycosylase domain protein, is required for endosperm gene imprinting and seed viability in arabidopsis. Cel/ 110: 33-42.

CHOUARD, P. (1960). Vernalization and its relations to dormancy. Ann Rev Plant Physiol 11: 191-238.

CZERMIN, B., MELFI, R., MCCABE, D., SEITZ, V., IMHOF, A. and PIRROTTA, V. (2002). Drosophila enhancer of zeste/esc complexes have a histone h3 methyltransferase activity that marks chromosomal polycomb sites. Ce// 111: 185-96.

DECAMILLIS, M., CHENG, N.S., PIERRE, D. and BROCK, H.W. (1992). The polyhomeotic gene of Drosophila encodes a chromatin protein that shares polytene chromosome-binding sites with polycomb. Genes Dev. 6: 223-32.

DELAVAL, K. and FEIL, R. (2004). Epigenetic regulation of mammalian genomic imprinting. Curr Opin Genet Dev 14: 188-95.

EBEL, C., MARICONTI, L. and GRUISSEM, W. (2004). Plant retinoblastoma homologues control nuclear proliferation in the female gametophyte. Nature 429: 776-80.

FRANKE, A., DECAMILLIS, M., ZINK, D., CHENG, N., BROCK, H.W. and PARO, R. (1992). Polycomb and polyhomeotic are constituents of a multimeric protein complex in chromatin of Drosophila melanogaster. EMBO journal, The 11: 2941-50.

GARCIA, D., FITZ GERALD, J.N. and BERGER, F. (2005). Maternal control of integument cell elongation and zygotic control of endosperm growth are coordinated to determine seed size in arabidopsis. Plant Cell 17: 52-60.

GARCIA, D., SAINGERY, V., CHAMBRIER, P., MAYER, U., JURGENS, G. and BERGER, F. (2003). Arabidopsis haiku mutants reveal new controls of seed size by endosperm. Plant physiology 131: 1661-70.

GENDALL, A.R., LEVY, Y.Y., WILSON, A. and DEAN, C. (2001). The vernalization 2 gene mediates the epigenetic regulation of vernalization in arabidopsis. Cell 107: 525-35.

GOODRICH, J., PUANGSOMLEE, P., MARTIN, M., LONG, D., MEYEROWITZ, E.M. and COUPLAND, G. (1997). A polycomb-group gene regulates homeotic gene expression in arabidopsis. Nature 386: 44-51.

GROSSNIKLAUS, U., VIELLE-CALZADA, J.P., HOEPPNER, M.A. and GAGLIANO, W.B. (1998). Maternal control of embryogenesis by medea, a polycomb group gene in arabidopsis. Science 280: 446-450.

GUITTON, A.E., PAGE, D.R., CHAMBRIER, P., LIONNET, C., FAURE, J.E., GROSSNIKLAUS, U. and BERGER, F. (2004). Identification of new members of fertilisation independent seed polycomb group pathway involved in the control of seed development in arabidopsis thaliana. Development 131: 2971 81.

GUITTON, A.E. and BERGER, F. (2005). Loss-of-function of MULTICOPYSUPPRESSOR OF IRA 1 produces non-viable parthenogenetic embryos in Arabidopsis. Curr. Biol. 15: 750-754.

GUNSTER, M.J., SATIJN, D.P., HAMER, K.M., DEN-BLAAUWEN, J.L., DEBRUIJN, D., ALKEMA, M.J., VAN-LOHUIZEN, M., VAN-DRIEL, R. and OTTE, A.P. (1997). Identification and characterization of interactions between the vertebrate polycomb-group protein bmi1 and human homologs of polyhomeotic. Mol. Cell Biol. 17: 2326-35.

HATA, K., OKANO, M., LEI, H. and LI, E. (2002). Dnmt3I cooperates with the dnmt3 family of de novo DNA methyltransferases to establish maternal imprints in mice. Development 129: 1983-93.

HENNIG, L., TARANTO, P., WALSER, M., SCHONROCK, N. and GRUISSEM, W. (2003). Arabidopsis msi 1 is required for epigenetic maintenance of reproductive development. Development 130: 2555-2565.

HOLDEMAN, R., NEHRT, S. and STROME, S. (1998). Mes-2, a maternal protein essential for viability of the germline in caenorhabditis elegans, is homologous to a Drosophila polycomb group protein. Development 125: 2457-67.

INGOUFF, M., FITZGERALD, J. N., GUÉRIN C., ROBERT, H., SØRENSEN, M. B., VAN DAMME, D., GEELEN, D. BLANCHOIN, L. and BERGER, F. (2005). Plant formin AtFH5 is an evolutionarily conserved actin nucleator involved in cytokinesis. Nat. Cell Biol. 7: 374-380.

INGOUFF, M. HASELOFF, J. and BERGER, F. (2005). Polycomb group genes control developmental timing of endosperm. Plant J. 42: 663-674

JOHANSON, U., WEST, J., LISTER, C., MICHAELS, S., AMASINO, R. and DEAN C. (2000). Molecular analysis of frigida, a major determinant of natural variation in arabidopsis flowering time. Science 290: 344-7.

JONES, C.A., NG, J., PETERSON, A.J., MORGAN, K., SIMON, J. and JONES, R.S (1998). The Drosophila esc and e(z) proteins are direct partners in polycomb group-mediated repression. Mol. Cell Biol. 18: 2825-34.

JONES, R.S. and GELBART, W.M. (1990). Genetic analysis of the enhancer of zeste locus and its role in gene regulation in Drosophila melanogaster. Genetics 126: $185-99$

JÜRGENS, G. (1985). A group of genes controlling the spatial expression of the bithorax complex in Drosophila. Nature 316: 153-155.

KANEDA, M., OKANO, M., HATA, K., SADO, T., TSUJIMOTO, N., LI, E. and SASAKI, H. (2004). Essential role for de novo DNA methyltransferase dnmt3a in paternal and maternal imprinting. Nature 429: 900-3.

KATZ, A., OLIVA, M., MOSQUNA, A., HAKIM, O. and OHAD, N. (2004a). Fie and curly leaf polycomb proteins interact in the regulation of homeobox gene expression during sporophyte development. Plant J. CellMol. Biol. 37: 707-19.

KINOSHITA, T., HARADA, J.J., GOLDBERG, R.B. and FISCHER, R.L. (2001). Polycomb repression of flowering during early plant development. Proc Nat/ Acad Sci USA 98: 14156-61.

KINOSHITA, T., MIURA, A., CHOI, Y., KINOSHITA, Y., CAO, X., JACOBSEN, S.E., FISCHER, R.L. and KAKUTANI, T. (2004). One-way control of fwa imprinting in arabidopsis endosperm by DNA methylation. Science 303: 521-3.

KINOSHITA, T., YADEGARI, R., HARADA, J.J., GOLDBERG, R.B. and FISCHER, R.L. (1999). Imprinting of the medea polycomb gene in the arabidopsis endosperm. Plant Cell 11: 1945-1952.

KIYOSUE, T., OHAD, N., YADEGARI, R., HANNON, M., DINNENY, J., WELLS, D., KATZ, A., MARGOSSIAN, L., HARADA, J.J., GOLDBERG, R.B. et al. (1999). Control of fertilization-independent endosperm development by the medea polycomb gene in arabidopsis. Proc. Natl. Acad. Sci. USA 96: 4186-91.

KOHLER, C., HENNIG, L., BOUVERET, R., GHEYSELINCK, J., GROSSNIKLAUS, $U$. and GRUISSEM, W. (2003a). Arabidopsis msi1 is a component of the mea/ fie polycomb group complex and required for seed development. EMBO J 22: 4804-4814.

KOHLER, C., HENNIG, L., SPILLANE, C., PIEN, S., GRUISSEM, W. and GROSSNIKLAUS, U. (2003b). The polycomb-group protein medea regulates seed development by controlling expression of the mads-box gene pheres 1 . 
Genes Dev. 17: 1540-53.

KOHLER, C., PAGE, D.R., GAGLIARDINI, V. and GROSSNIKLAUS, U. (2005). The arabidopsis thaliana medea polycomb group protein controls expression of pheres 1 by parental imprinting. Nat Genet 37: 28-30.

KORNBERG, R.D. (1974). Chromatin structure: A repeating unit of histones and DNA. Science 184: 868-71.

KORNBERG, R.D. and THOMAS, J.O. (1974). Chromatin structure; oligomers of the histones. Science 184: 865-8.

KUZMICHEV, A., NISHIOKA, K., ERDJUMENT-BROMAGE, H., TEMPST, P. and REINBERG, D. (2002). Histone methyltransferase activity associated with a human multiprotein complex containing the enhancer of zeste protein. Genes Dev. 16: 2893-905.

LESSARD, J. and SAUVAGEAU, G. (2003a). Bmi-1 determines the proliferative capacity of normal and leukaemic stem cells. Nature 423: 255-60.

LESSARD, J. and SAUVAGEAU, G. (2003b). Polycomb group genes as epigenetic regulators of normal and leukemic hemopoiesis. Exp. Hematol. 31: 567-85.

LEVY, Y.Y., MESNAGE, S., MYLNE, J.S., GENDALL, A.R. and DEAN, C. (2002). Multiple roles of arabidopsis vrn1 in vernalization and flowering time control. Science 297: 243-6.

LEWIS, A., MITSUYA, K., UMLAUF, D., SMITH, P., DEAN, W., WALTER, J., HIGGINS, M., FEIL, R. and REIK, W. (2004). Imprinting on distal chromosome 7 in the placenta involves repressive histone methylation independent of DNA methylation. Nat Genet 36: 1291-5.

LEWIS, E.B. (1978). A gene complex controlling segmentation in Drosophila. Nature 276: 565-70.

LUGER, K. and RICHMOND, T.J. (1998). The histone tails of the nucleosome. Curr. Opin. Genet. Dev. 8: 140-6.

LUO, M., BILODEAU, P., DENNIS, E.S., PEACOCK, W.J. and CHAUDHURY, A. (2000). Expression and parent-of-origin effects for fis2, mea and fie in the endosperm and embryo of developing arabidopsis seeds. Proc. Natl. Acad. Sci. USA 97: 10637-10642.

LUO, M., BILODEAU, P., KOLTUNOW, A., DENNIS, E.S., PEACOCK, W.J. and CHAUDHURY, A.M. (1999). Genes controlling fertilization-independent seed development in arabidopsis thaliana. Proc Nat/ Acad Sci USA 96: 296-301.

MAGER, J., MONTGOMERY, N.D., DE VILLENA, F.P. and MAGNUSON, T. (2003). Genome imprinting regulated by the mouse polycomb group protein eed. Nat Genet 33: 502-7.

MANDEL, M.A., GUSTAFSON-BROWN, C., SAVIDGE, B. and YANOFSKY, M.F. (1992). Molecular characterization of the arabidopsis floral homeotic gene apetala1. Nature 360: 273-7.

MANDEL, M.A. and YANOFSKY, M.F. (1995). A gene triggering flower formation in arabidopsis. Nature 377: 522-4.

METZGER, J.D. (1988). Localization of the site of perception of thermoinductive tempereatures in thlaspi arvense I. Plant Physiol 88: 424-428.

MICHAELS, S.D. and AMASINO, R.M. (1999). Flowering locus c encodes a novel mads domain protein that acts as a repressor of flowering. Plant Cel/ 11: 94956.

MOON, Y.H., CHEN, L., PAN, R.L., CHANG, H.S., ZHU, T., MAFFEO, D.M. and SUNG, Z.R. (2003). Emf genes maintain vegetative development by repressing the flower program in arabidopsis. Plant Cell 15: 681-93.

MOSQUNA, A., KATZ, A., SHOCHAT, S., GRAFI, G. and OHAD, N. (2004). Interaction of fie, a polycomb protein, with prb: A possible mechanism regulating endosperm development. Mol Genet Genomics 271: 651-7.

MÜLLER, J., HART, C.M., FRANCIS, N.J., VARGAS, M.L., SENGUPTA, A., WILD, B., MILLER, E.L., O'CONNOR, M.B., KINGSTON, R.E. and SIMON, J.A. (2002). Histone methyltransferase activity of a Drosophila polycomb group repressor complex. Cell 111: 197-208.

NG, J., HART, C.M., MORGAN, K. and SIMON, J.A. (2000). A Drosophila esc-e(z) protein complex is distinct from other polycomb group complexes and contains covalently modified esc. Mol. Cell Biol. 20: 3069-78.

OHAD, N., MARGOSSIAN, L., HSU, Y.C., WILLIAMS, C., REPETTI, P. and FISCHER, R.L. (1996). A mutation that allows endosperm development without fertilization. Proc Nat/ Acad Sci USA 93: 5319-24.

OHAD, N., YADEGARI, R., MARGOSSIAN, L., HANNON, M., MICHAELI, D., HARADA, J.J., GOLDBERG, R.B. and FISCHER, R.L. (1999). Mutations in fie, a wd polycomb group gene, allow endosperm development without fertilization. Plant Cell 11: 407-16.

OHTA, H., SAWADA, A., KIM, J.Y., TOKIMASA, S., NISHIGUCHI, S., HUMPHRIES, R.K., HARA, J. and TAKIHARA, Y. (2002). Polycomb group gene rae28 is required for sustaining activity of hematopoietic stem cells. J. Exp. Med. 195: 759-70.

OKANO, M., BELL, D.W., HABER, D.A. and LI, E. (1999). DNA methyltransferases dnmt3a and dnmt3b are essential for de novo methylation and mammalian development. Cel/ 99: 247-57.

OKANO, M. and LI, E. (2002). Genetic analyses of DNA methyltransferase genes in mouse model system. J Nutr 132: 2462S-2465S.

ONG, K., KRATZSCH, J., KIESS, W., COSTELLO, M., SCOTT, C. and DUNGER, D. (2000). Size at birth and cord blood levels of insulin, insulin-like growth factor i (igf-i), igf-ii, igf-binding protein-1 (igfbp-1), igfbp-3 and the soluble igf-ii/ mannose-6-phosphate receptor in term human infants. The alspac study team. Avon longitudinal study of pregnancy and childhood. $J$ Clin Endocrinol Metab 85: 4266-9.

PEACOCK, J., MING, L., CRAIG, S., DENNIS, E. and CHAUDHURY, A. (1995). A mutagenesis programme for apomixis genes in arabidopsis. In Induced Mutations and Molecular Techniques for Crop Improvement, (ed., pp. 117-125. Vienna, Austria: IAEA.

RASTELLI, L., CHAN, C.S. and PIRROTTA, V. (1993). Related chromosome binding sites for zeste, suppressors of zeste and polycomb group proteins in Drosophila and their dependence on enhancer of zeste function. EMBO J. 12: 1513-22.

REIK, W., CONSTANCIA, M., FOWDEN, A. andERSON, N., DEAN, W., FERGUSONSMITH, A., TYCKO, B. and SIBLEY, C. (2003). Regulation of supply and demand for maternal nutrients in mammals by imprinted genes. J. Physiology 547: 35-44

REIK, W. and WALTER, J. (2001). Genomic imprinting: Parental influence on the genome. Nature Reviews 2: 21-32.

SATIJN, D.P., HAMER, K.M., DEN-BLAAUWEN, J. and OTTE, A.P. (2001). The polycomb group protein eed interacts with yy1 and both proteins induce neural tissue in Xenopus embryos. Mol. Cell Biol. 21: 1360-9.

SAURIN, A.J., SHAO, Z., ERDJUMENT-BROMAGE, H., TEMPST, P. and KINGSTON, R.E. (2001). A Drosophila polycomb group complex includes zeste and dtafii proteins. Nature 412: 655-60.

SCHWABE, W.W. (1954). Factors controlling flowering in the chrysanthemum iv. The site of vernalization and translocation of the stimulus. J Exp Bot 5: 538-341.

SCOTT, R.J., SPIELMAN, M., BAILEY, J. and DICKINSON, H.G. (1998). Parentof-origin effects on seed development in arabidopsis thaliana. Development 125: 3329-41.

SEWALT, R.G., VAN-DER-VLAG, J., GUNSTER, M.J., HAMER, K.M., DENBLAAUWEN, J.L., SATIJN, D.P., HENDRIX, T., VAN-DRIEL, R. and OTTE, A.P. (1998). Characterization of interactions between the mammalian polycombgroup proteins enx1/ezh2 and eed suggests the existence of different mammalian polycomb-group protein complexes. Mol. Cell Biol. 18: 3586-95.

SHAO, Z., RAIBLE, F., MOLLAAGHABABA, R., GUYON, J.R., WU, C.T., BENDER, W. and KINGSTON, R.E. (1999). Stabilization of chromatin structure by prc1, a polycomb complex. Cell 98: 37-46.

SHELdON, C.C., BURN, J.E., PEREZ, P.P., METZGER, J., EDWARDS, J.A., PEACOCK, W.J. and DENNIS, E.S. (1999). The flf mads box gene: A repressor of flowering in arabidopsis regulated by vernalization and methylation. Plant Cell 11: 445-58.

SHELDON, C.C., CONN, A.B., DENNIS, E.S. and PEACOCK, W.J. (2002). Different regulatory regions are required for the vernalization-induced repression of flowering locus $\mathrm{c}$ and for the epigenetic maintenance of repression. Plant Cell 14: 2527-37.

SIMON, J., CHIANG, A. and BENDER, W. (1992). Ten different polycomb group genes are required for spatial control of the abda and $\mathrm{abdb}$ homeotic products. Development 114: 493-505.

SORENSEN, M.B., CHAUDHURY, A.M., ROBERT, H., BANCHAREL, E. and BERGER, F. (2001). Polycomb group genes control pattern formation in plant seed. Current Biology 11: 277-281.

SORENSEN, M.B., MAYER, U., LUKOWITZ, W., ROBERT, H., CHAMBRIER, P., JURGENS, G., SOMERVILLE, C., LEPINIEC, L. and BERGER, F. (2002). 


\section{A.E. Guitton and F. Berger}

Cellularisation in the endosperm of arabidopsis thaliana is coupled to mitosis and shares multiple components with cytokinesis. Development 129: 5567-76.

SPILLANE, C., MACDOUGALL, C., STOCK, C., KOHLER, C., VIELLE-CALZADA, J.P., NUNES, S.M., GROSSNIKLAUS, U. and GOODRICH, J. (2000). Interaction of the arabidopsis polycomb group proteins fie and mea mediates their common phenotypes. Curr Biol 10: 1535-8.

STRUHL, G. and AKAM, M. (1985). Altered distributions of ultrabithorax transcripts in extra sex combs mutant embryos of Drosophila. EMBO J. 4: 3259-64.

SUETAKE, I., SHINOZAKI, F., MIYAGAWA, J., TAKESHIMA, H. and TAJIMA, S. (2004). Dnmt3l stimulates the DNA methylation activity of dnmt3a and dnmt3b through a direct interaction. J Biol Chem 279: 27816-23.

SUNG, S. and AMASINO, R.M. (2004). Vernalization in arabidopsis thaliana is mediated by the phd finger protein vin3. Nature 427: 159-64.

SURANI, M.A., BARTON, S.C. and NORRIS, M.L. (1984). Development of reconstituted mouse eggs suggests imprinting of the genome during gametogenesis. Nature 308: 548-50.

TIE, F., FURUYAMA, T. and HARTE, P.J. (1998). The Drosophila polycomb group proteins esc and $\mathrm{e}(\mathrm{z})$ bind directly to each other and co-localize at multiple chromosomal sites. Development 125: 3483-96.

TIE, F., FURUYAMA, T., PRASAD-SINHA, J., JANE, E. and HARTE, P.J. (2001). The Drosophila polycomb group proteins esc and $\mathrm{e}(\mathrm{z})$ are present in a complex containing the histone-binding protein p55 and the histone deacetylase rpd3. Development 128: 275-86.

UMLAUF, D., GOTO, Y., CAO, R., CERQUEIRA, F., WAGSCHAL, A., ZHANG, Y. and FEIL, R. (2004). Imprinting along the kcnq1 domain on mouse chromosome 7 involves repressive histone methylation and recruitment of polycomb group complexes. Nat Genet 36: 1296-300.

VAN-DER-VLAG, J. and OTTE, A.P. (1999). Transcriptional repression mediated by the human polycomb-group protein eed involves histone deacetylation. Nature Genet. 23: 474-8.

VAN-LOHUIZEN, M., TIJMS, M., VONCKEN, J.W., SCHUMACHER, A., MAGNUSON, T. and WIENTJENS, E. (1998). Interaction of mouse polycomb-group (pc-g) proteins enx 1 and enx 2 with eed: Indication for separate pc-g complexes. Mol. Cel/
Biol. 18: 3572-9.

VIELLE-CALZADA, J.P., THOMAS, J., SPILLANE, C., COLUCCIO, A., HOEPPNER, M.A. and GROSSNIKLAUS, U. (1999). Maintenance of genomic imprinting at the arabidopsis medea locus requires zygotic ddm1 activity. Genes Dev. 13: 29712982.

WEIGEL, D., ALVAREZ, J., SMYTH, D.R., YANOFSKY, M.F. and MEYEROWITZ, E.M. (1992). Leafy controls floral meristem identity in arabidopsis. Cel/ 69: 84359.

WEIGEL, D. and NILSSON, O. (1995). A developmental switch sufficient for flower initiation in diverse plants. Nature 377: 495-500.

WOLFFE, A.P. and HAYES, J.J. (1999). Chromatin disruption and modification. Nuc. Acids Res. 27: 711-20.

XIAO, W., GEHRING, M., CHOI, Y., MARGOSSIAN, L., PU, H., HARADA, J.J., GOLDBERG, R.B., PENNELL, R.I. and FISCHER, R.L. (2003). Imprinting of the mea polycomb gene is controlled by antagonism between met1 methyltransferase and dme glycosylase. Developmental cell 5: 891-901.

YADEGARI, R., KINOSHITA, T., LOTAN, O., COHEN, G., KATZ, A., CHOI, Y., NAKASHIMA, K., HARADA, J.J., GOLDBERG, R.B., FISCHER, R.L. et al. (2000) Mutations in the fie and mea genes that encode interacting polycomb proteins cause parent-of-origin effects on seed development by distinct mechanisms. Plant Cell 12: 2367-2381.

YAMAMOTO, K., SONODA, M., INOKUCHI, J., SHIRASAWA, S. and SASAZUKI, T. (2004). Polycomb group suppressor of zeste 12 links heterochromatin protein 1alpha and enhancer of zeste 2. J. Biol. Chem. 279: 401-406.

YANG, C.H., CHEN, L.J. and SUNG, Z.R. (1995). Genetic regulation of shoot development in arabidopsis: Role of the emf genes. Dev. Biol. 169: 421-35.

YOSHIDA, N., YANAI, Y., CHEN, L., KATO, Y., HIRATSUKA, J., MIWA, T., SUNG Z.R. and TAKAHASHI, S. (2001). Embryonic flower2, a novel polycomb group protein homolog, mediates shoot development and flowering in arabidopsis. Plant Cell 13: 2471-81.

ZINK, B. and PARO, R. (1989). In vivo binding pattern of a trans-regulator of homoeotic genes in Drosophila melanogaster. Nature 337: 468-71. 